\title{
Experimental Toxoplasmosis in BALB/c Mice. Prevention of Vertical Disease Transmission by Treatment and Reproductive Failure in Chronic Infection
}

\author{
B Fux, AM Ferreira, GD Cassali, WL Tafuri, RWA Vitor ${ }^{+}$ \\ Departamento de Parasitologia, Instituto de Ciências Biológicas, Universidade Federal de Minas Gerais, \\ Caixa Postal 486, 31270-901 Belo Horizonte, MG, Brasil
}

In a study of congenital transmission during acute infection of Toxoplasma gondii, 23 pregnant $B A L B / c$ mice were inoculated orally with two cysts each of the P strain. Eight mice were inoculated 6-11 days after becoming pregnant (Group 1). Eight mice inoculated on the 10th-15th day of pregnancy (Group 2) were treated with $100 \mathrm{mg} / \mathrm{kg} /$ day of minocycline $48 \mathrm{~h}$ after inoculation. Seven mice inoculated on the 10th-15th day of pregnancy were not treated and served as a control (Group 3). Congenital transmission was evaluated through direct examination of the brains of the pups or by bioassay and serologic tests. Congenital transmission was observed in 20 (60.6\%) of the 33 pups of Group 1, in one (3.6\%) of the 28 pups of Group 2, and in 13 (54.2\%) of the 24 pups of Group 3. Forty-nine Balb/c mice were examined in the study of congenital transmission of $\mathrm{T}$. gondii during chronic infection. The females showed reproductive problems during this phase of infection. It was observed accentuated hypertrophy of the endometrium and myometrium. Only two of the females gave birth. Our results demonstrate that Balb/c mice with acute toxoplasmosis can be used as a model for studies of congenital $\mathrm{T}$. gondii infection. Our observations indicate the potential of this model for testing new chemotherapeutic agents against congenital toxoplasmosis.

Key words: Toxoplasma gondii - BALB/c mice - congenital transmission

Toxoplasma gondii infection is a common congenital disease in humans and domestic animals. Congenital toxoplasmosis is one of the principal causes of abortion, foetal death, and stillbirths in sheep, goats and pigs (Dubey \& Beattie 1988). Severe cases occur with greater frequency when the mother is infected during the first two trimesters of pregnancy. When acquired later, symptoms tend to be subclinical or even lacking in the foetus (Desmonts \& Couvreur 1974).

Numerous animal models, including primates, rabbits, guinea pigs, hamsters, mice and rats, have been used in recent years to study the pathology of the infection and the efficacy of vaccines and new drugs for the treatment of congenital transmission, chorioretinitis and toxoplasmic encephalitis. Of these, mice have been found to be the most susceptible to $T$. gondii and are particularly interest-

\footnotetext{
This study was supported by Fundação de Amparo à Pesquisa do Estado de Minas Gerais (Fapemig). ${ }^{+}$Corresponding author. Fax: +55-31-499.2970. E-mail: vitorrwa@mono.icb.ufmg.br Received 21 July 1999

Accepted 4 November 1999
}

ing model to study congenital infection.

Roberts and Alexander (1992) demonstrated that vertical Toxoplasma transmission only occurs in Balb/c mice infected with $T$. gondii for the first time during pregnancy. It was observed that vaccination with a $T$. gondii antigen enveloped in lipid vesicles significantly reduced the incidence of abortion in mice (Roberts et al. 1994). Recently Alexander et al. (1998) observed aspects of cellular immunity using this model, and demonstrated that IL-4 is associated with pregnancy-induced immunosuppression.

In this paper, we report on a study of congenital toxoplasmosis in Balb/c mice infected with a strain of $T$. gondii isolated in Brazil, which gave particular high ratio of congenital transmission during acute toxoplasmosis. The incidence of congenital transmission in Balb/c females treated with minocycline was evaluated.

\section{MATERIALS AND METHODS}

Mice - Female BALB/c mice were maintained and bred under conventional laboratory conditions at the Federal University of Minas Gerais, Belo Horizonte, Brazil. A total of 97 mice were used in the study: 72 females and 25 males. All were serologically negative for toxoplasmosis.

Infection - The cysts used for the experimental infection were obtained from the brains of Swiss 
mice after 30 days of infection with the $\mathrm{P}$ strain of T. gondii. This strain was isolated from a dog in Brazil (Jamra \& Vieira 1991). The mice were sacrificed by cervical dislocation; the brains were removed and homogenised in phosphate buffered saline (PBS) pH 7.2. Mice were infected orally with two cysts either eight weeks prior to mating or between the 6th and 15th day of pregnancy. Eight mice inoculated between the 10th and 15th days of pregnancy were treated with $100 \mathrm{mg} / \mathrm{kg} /$ day of minocycline until the birth of their offspring (Chang et al. 1991). Details of each experimental group are shown in Table I.

Mating - Uninfected female mice, mice infected between 6th and 15th days after mating, and those with chronic infections of 60,75 or 90 days, were maintained with a male for seven days. Immediately after giving birth, the experimentally infected mothers were substituted by uninfected foster mothers to avoid possible transmission through suckling.

Detection of congenital infection - Detection of congenital infection was carried out directly through examination for cysts in the brain of the newborn mice, by bioassay of neonate tissues and by the following serologic tests: indirect fluorescent antibody test (IFAT), enzyme linked immunosorbent assay (ELISA) and Western blotting (WB). For the direct examination, the brains of the newborn offspring were removed and homogenised in PBS pH 7.2, and the suspension was placed on a slide, mounted under a cover slip, and viewed under a light microscope. The bioassay of neonate tissues was carried out on the newborn offspring, which died during the experimental period (the incidence of neonate mortality was high due to rejection after fostering). The brain, heart, lungs and liver were macerated in $1 \mathrm{ml}$ of PBS pH 7.2 and inoculated into the peritoneal cavity of Swiss mice. These mice were evaluated after 30 days by parasitological and serologic tests.

Ifat was carried out, using the procedure outlined by Camargo (1964), on the appropriate slides containing formalin fixed Toxoplasma tachyzoites. Plasma was diluted in PBS pH 7.2 for the IgM class antibody (1:4 to $1: 256)$, and for IgG class antibodies $(1: 16$ to $1: 16000)$.

ELISA was carried out using a modification of the procedure described by Voller et al. (1976). Antigen was obtained by sonication of tachyzoites in a Branson sonicator at 20 watts for $30 \mathrm{sec}$ at $4{ }^{\circ} \mathrm{C}$. Plasma was diluted 1:64 in PBS-tween-20 at 0.05\%, in duplicate and incubated at $37^{\circ} \mathrm{C}$ for $45 \mathrm{~min}$. The plaque was then washed and $100 \mu \mathrm{l}$ of peroxidase conjugated $\operatorname{IgG}, \operatorname{IgM}$ or $\operatorname{IgA}$ mouse anti-immunoglobulin was added to each well. The reaction was visualised with orto-phenylenodiamine and stopped with $4 \mathrm{~N}-\mathrm{H} 2 \mathrm{SO} 4$. Absorbance was read at $490 \mathrm{~nm}$ on a Microplaque Reader Biorad 3550. The values were considered positive when they were above the mean absorbance obtained for four non-reactive plasma, plus three standard deviations (cut off).

WB was performed by a modification of the procedure described by Towbin et al. (1979). Purified tachyzoites were dissolved in sample buffer and eletrophoresed on $12.5 \%$ polyacrylamide gels. The standards used for molecular weights $(66,45$, 24, 18 and $14 \mathrm{kDa}$ ) were from Sigma (MW-SDS$70 \mathrm{~L}$ ). After separation by sodium dodecyl sulphatepolyacrylamide gel electrophoresis, proteins were transferred to nitro-cellulose membranes at $20 \mathrm{~h}$ at $30 \mathrm{~V}$ and $40 \mathrm{~mA}$. The detection of proteins was carried out by an immunoenzymatic method in 3 $\mathrm{mm}$ strips. Proteins were shown up by developing strips using 4-chloro-1naphthol. Positive (plasma of mice inoculated orally with two cysts 60 days after infection) and negative (plasma of normal mice) controls were used in all the tests.

Histopathology - A histological examination was carried out on the reproductive systems of nine female BALB/c mice infected for 60 days (Group 4). Five normal females of the same age were sacrificed at the same time. The uterus, ovaries and brain were removed immediately and fixed in $10 \%$ formalin/PBS pH 7.2. Following processing, the samples were set in paraffin and sectioned in slices of $4 \mu \mathrm{m}$ width. The material was then stained with haematoxilin-eosin and examined under a light microscope. Mice of Groups 5 and 6 were not subjected to histological analysis.

TABLE I

Incidence of congenital toxoplasmosis infection in BALB/c mice inoculated with $\mathrm{P}$ strain of Toxoplasma gondii

\begin{tabular}{cclc}
\hline Group & $\begin{array}{c}\text { No. of infected } \\
\text { mothers }\end{array}$ & Time of infection of the mothers & $\begin{array}{c}\text { No. of infected pups } \\
\text { (total pups \%) }\end{array}$ \\
\hline 1 & 8 & 6th to 11th days after mating & $20 / 33(60.6)$ \\
2 & 8 & 10th to 15th days after mating (treated with minocycline) & $1 / 28(3.6)$ \\
3 & 7 & 10th to 15th days after mating & $13 / 24(54.2)$ \\
4 & 9 & 60 days before mating & 0 \\
5 & 12 & 75 days before mating & $0 / 1$ \\
6 & 28 & 90 days before mating & $0 / 1$ \\
\hline
\end{tabular}




\section{RESULTS}

Congenital transmission of T.gondii during the acute phase - The incidence of congenital toxoplasmosis in the experimental groups is summarised in Table I. Congenital toxoplasmosis in Group 1 was observed in seven of the eight females inoculated $(87.5 \%)$ with $20(60.6 \%)$ pups positive for brain cysts or by bioassays. Antibody response was evaluated in 19 30-day-old mice (Table II). IgG antibodies detected by Ifat showed 95\% concordance with the parasitological diagnosis. Fourteen of 19 pups $(73.7 \%)$ showed titres of between $1: 16$ and 1:256 for the IFAT-IgG, 13 also with positive parasitological tests. The IFAT-IgM detected six $(31.6 \%)$ of the mice with a titre of $1: 4$, five of them with positive parasitological results. In the ELISA-IgG, only five pups $(26.3 \%)$ showed an absorbance of $\geq 0.094$ (cut off-IgG). In the ELISA-IgM, 12 pups $(63.2 \%)$ showed an absorbance of $\geq 0.079$ (cut off- $\operatorname{IgM}$ ), and in the ELISA-IgA four pups $(21.0 \%)$ showed an absorbance of $\geq 0,068$ (cut off-IgM). In the WB-IgG, $15(78.9 \%)$ of the pups evaluated recognised $T$. gondii antigens. The principal bands had molecular weights of 32, 22 and $19 \mathrm{kDa}$. Representative results obtained from mothers $1,2,3$ and 4 are shown in Fig.1. The mothers' plasma recognised the largest number of antigens, with a profile similar to that detected in the positive control mice.

In Group 2, eight females were inoculated between the 10th and 15th day of pregnancy and treated with $100 \mathrm{mg} / \mathrm{kg} / \mathrm{day}$ of minocycline. Congenital transmission was observed in only one (3.6\%) of the 28 pups (Table I). All of the pups evaluated by IFAT and ELISA gave negative results, except for one, which was positive for IfatIgG, IgM and ELISA-IgM, but negative for ELISA-IgG and IgA. Eight females which had not been treated with minocycline were evaluated simultaneously (Group 3). Congenital toxoplasmosis was recorded for six $(85.7 \%)$ of the seven females inoculated, with $13(54.2 \%)$ of the 24 pups positive. The antibody response was evaluated by IFAT and ELISA in 20 pups 30 days after they were born (Table II). Similar to Group 1, 55\% of the offspring gave titres $\geq 1: 16$ in IFAT-IgG and $50 \%$ showed titres $\geq 1: 4$ in IFAT-IgM. All the 13 pups had brain cysts and showed a positive bioassay, with a high concordance with Ifat. All of the pups evaluated by the ELISA-IgG, showed absorbance

\section{TABLE II}

Search for parasite by bioassay, brain cysts and serum antibody response by indirect fluorescent antibody test (IFAT), enzyme linked immunosorbent assay (ELISA) and Western blotting (WB), of pups born from BALB/c mice inoculated with $\mathrm{P}$ strain of Toxoplasma gondii

\begin{tabular}{|c|c|c|c|c|c|c|c|c|}
\hline Mother & Pup & $\begin{array}{c}\text { Brain cyst or } \\
\text { bioassay }\end{array}$ & $\begin{array}{l}\text { IFAT } \\
\text { IgG }\end{array}$ & $\begin{array}{l}\text { IFAT } \\
\text { IgM }\end{array}$ & $\begin{array}{c}\text { ELISA } \\
\text { IgG }\end{array}$ & $\begin{array}{c}\text { ELISA } \\
\text { IgM }\end{array}$ & $\begin{array}{c}\text { ELISA } \\
\text { IgA }\end{array}$ & $\begin{array}{l}\text { WB } \\
\text { IgG }\end{array}$ \\
\hline \multirow[t]{2}{*}{1} & 1 & + & + & + & + & + & - & + \\
\hline & 2 & - & $\mathrm{NCO}$ & $\mathrm{NCO}$ & $\mathrm{NCO}$ & $\mathrm{NCO}$ & $\mathrm{NCO}$ & $\mathrm{NCO}$ \\
\hline \multirow[t]{2}{*}{2} & $1-3$ & - & - & - & - & - & - & - \\
\hline & $4-8$ & - & NCO & $\mathrm{NCO}$ & $\mathrm{NCO}$ & $\mathrm{NCO}$ & $\mathrm{NCO}$ & $\mathrm{NCO}$ \\
\hline \multirow[t]{4}{*}{3} & 1 & + & + & + & - & + & - & + \\
\hline & 2 & + & + & + & - & + & - & + \\
\hline & 3 & + & - & + & - & + & + & + \\
\hline & 4 & + & $\mathrm{NCO}$ & $\mathrm{NCO}$ & $\mathrm{NCO}$ & $\mathrm{NCO}$ & $\mathrm{NCO}$ & $\mathrm{NCO}$ \\
\hline \multirow[t]{3}{*}{4} & 1 & - & - & - & - & - & - & - \\
\hline & 2 & + & + & - & - & + & + & + \\
\hline & 3 & - & $\mathrm{NCO}$ & $\mathrm{NCO}$ & $\mathrm{NCO}$ & NCO & $\mathrm{NCO}$ & $\mathrm{NCO}$ \\
\hline \multirow[t]{4}{*}{5} & 1 & - & + & + & - & + & + & + \\
\hline & 2 & + & + & - & + & + & - & + \\
\hline & 3 & + & + & - & - & + & - & + \\
\hline & $4-5$ & + & $\mathrm{NCO}$ & $\mathrm{NCO}$ & $\mathrm{NCO}$ & $\mathrm{NCO}$ & $\mathrm{NCO}$ & $\mathrm{NCO}$ \\
\hline \multirow[t]{4}{*}{6} & 1 & + & + & - & - & + & - & + \\
\hline & 2 & + & + & - & - & + & + & + \\
\hline & 3 & + & + & + & - & + & - & + \\
\hline & 4 & - & $\mathrm{NCO}$ & $\mathrm{NCO}$ & $\mathrm{NCO}$ & NCO & NCO & $\mathrm{NCO}$ \\
\hline \multirow[t]{4}{*}{7} & 1 & + & + & - & - & - & - & + \\
\hline & 2 & + & + & - & + & + & - & + \\
\hline & 3 & + & + & - & + & - & - & + \\
\hline & 4 & + & + & - & + & - & - & + \\
\hline 8 & $1-3$ & + & $\mathrm{NCO}$ & $\mathrm{NCO}$ & $\mathrm{NCO}$ & $\mathrm{NCO}$ & $\mathrm{NCO}$ & $\mathrm{NCO}$ \\
\hline
\end{tabular}

+: positive; -: negative; NCO: not carried out. 


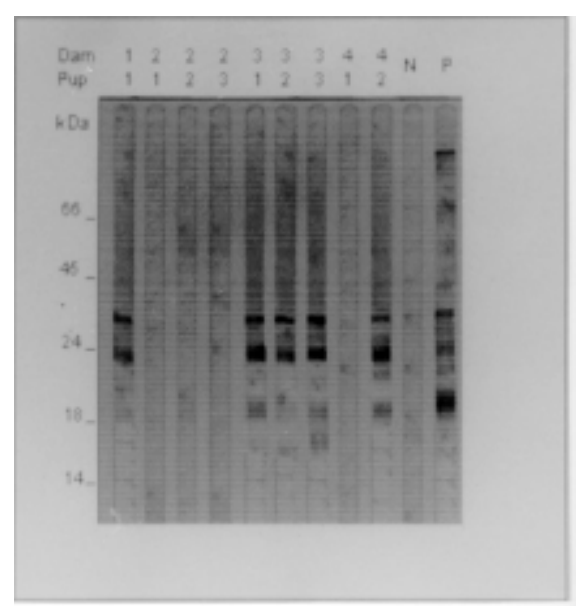

Fig. 1: Western blotting obtained from BALB/c mice born from mothers inoculated with Toxoplasma gondii 6-11 days of pregnancy. Pups from mothers 1, 2, 3 and 4 (Group 1). N: negative control; P: positive control. The apparent molecular weight (kilodaltons) of protein standards are given on the left side.
$<0.094$ (cut off). Five of them, evaluated 60 days after birth, showed absorbance values $\geq 0.094$. Only 16 pups were evaluated at birth with the ELISA-IgM, and $31.2 \%$ showed absorbance values $\geq 0.079$. Thirteen pups were evaluated with the ELISA-IgA, and only 1 (7.7\%) showed absorbance $\geq 0.068$.

Congenital transmission of $T$. gondii during the chronic phase of infection - Reproductive failure during, and probably related to, the chronic phase of $T$. gondii infection was recorded in Groups 4, 5 and 6 (Table I). Only two females gave birth. The pups of these two mothers showed no signs of infection when tested for cysts in the brain, and were negative by bioassay and IFAT. Histological examination of Group 4 females showed accentuated hypertrophy of the endometrium and myometrium (Fig. 2). A tendency for a reduction in folliculogenesis and the formation of corpora lutea in the ovaries when compared to the uninfected animals was also noted. No cysts were found in the uterus or ovaries of these animals.

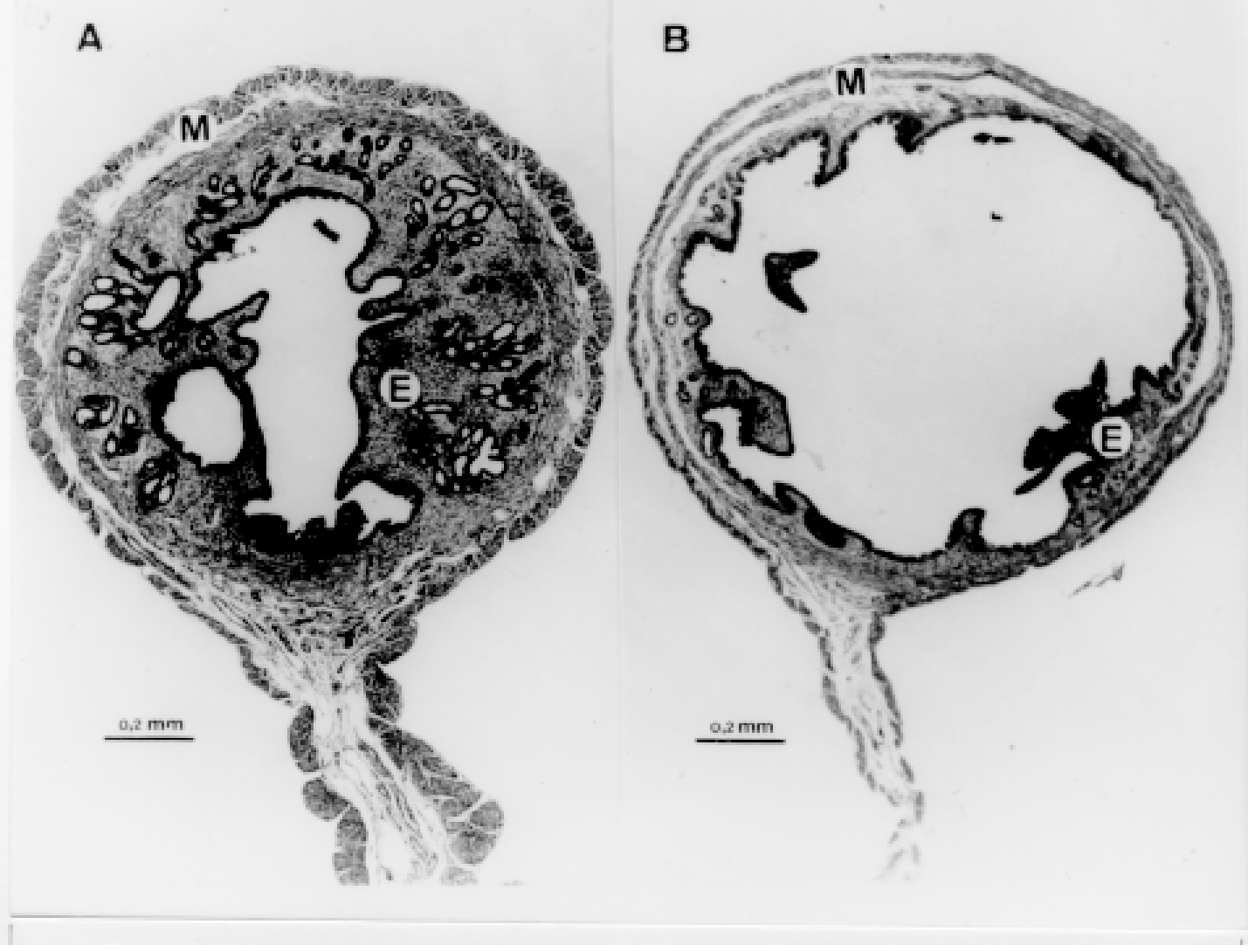

Fig. 2: histopathology of the uterus of BALB/c mice with Toxoplasma gondii in the chronic phase. A: uninfected BALB/c mice uterus without apparent alteration; B: chronically infected BALB/c mice - uterus with accentuated hypertrophy of the endometrium (E) and myometrium (M) (hematoxilin-eosin). 


\section{DISCUSSION}

Congenital toxoplasmosis was observed in $\mathrm{BALB} / \mathrm{c}$ mice during the acute phase of infection with the $\mathrm{P}$ strain of $T$. gondii. The incidence of infected pups was $60.6 \%$ (Group 1). These results are in agreement with those of Roberts and Alexander (1992) who observed approximately a $50 \%$ rate of infection in BALB/c pups examined using mice infected orally with 20 cysts of the RRA (Beverley) strain of $T$. gondii. All of the eight mice from Group 2 infected during pregnancy but treated with minocycline [using the scheme proposed by Chang et al. (1991)], gave birth. This treatment was, therefore, sufficient to prevent the vertical transmission of T. gondii. Only one pup (3.6\%) was born infected, while in Group 3 (untreated control) $13(54.2 \%)$ of the pups were congenitally infected. These results indicate the potential of this model for testing new chemotherapeutic agents against congenital toxoplasmosis.

Pups of Group 1 were tested for $T$. gondii antibodies at 30 days old. IFAT-IgG showed a concordance of $95 \%$ with the presence of brain cysts, while the ELISA showed a concordance of 53\%. The ELISA-IgM and IgA also showed a low concordance with the presence of brain cysts. A concordance of $100 \%$ between the IFAT-IgG and IgM and the presence of brain cysts was recorded in Group 3. In this group, ELISA-IgG gave falsenegative results for the plasma collected from all of the 30-day-old pups. At 60 days old, $50 \%$ of the congenitally infected pups were ELISA-IgG positive, suggesting a delay in the initiation of the specific antibody response to $T$. gondii. Roberts and Alexander (1992) used an ELISA-IgG to diagnose infection in eight-week-old BALB/c pups, and obtained a $100 \%$ correlation with the bioassay. The results obtained from WB in Group 1 may, in part, help in our understanding of the low sensitivity of the ELISA in our model, as well as the discrepancies with the results of Roberts and Alexander (1992). The WB showed a high concordance with the examination for brain cysts. However, few antigens were recognised, the majority of them between 15 e $35 \mathrm{kDa}$. These antigens, probably some of the principal components of the surface of the tachyzoites (SAG1 and SAG2), are highly immunogenic and responsible for the intense antibody response in the acute phase of toxoplasmosis (Wong \& Remington 1993). Positive results in the IFAT for the 30-day-old pups are probably due to the recognition of these tachyzoite surface-dominant antigens. It is probable that the low sensitivity of the ELISA test in diagnosing the infection in 30-day-old pups is related to deficiencies in the extraction of membrane components by sonication.
In our study of vertical transmission during the chronic phase of toxoplasmosis [defined by Suzuki et al. (1993) as the period 30 days after infection], only two females gave birth. After 60 days of infection, the females showed signs of uterine and ovarian atrophy, probably resulting in the reproductive failures we observed. However, T. gondii cysts were not found in the uterine tissue of Balb/ $\mathrm{c}$ mice in the chronic phase. This fact may be related to the size of the inoculum, the strain used, or be due to the sections examined. It is possible that examination of the sections used in immunoenzyme assays would have detected the parasites. Roberts and Alexander (1992) did not record reproductive problems with this model. They showed that BALB/c pups born during the chronic phase of toxoplasmosis were protected from congenital infection, contrary to the situation with other mouse lineages (Remington et al. 1960). Stahl and Turek (1988), however, also recorded reproductive failures and uterine atrophy in Nya: NYLAR mice inoculated with the CORNELL strain of $T$. gondii. It was probably also occurring in our model, and may be related to the virulence or the tropism of the $T$. gondii strain used in this study.

In conclusion, BALB/c mice present a satisfactory model for research on congenital toxoplasmosis, suitable for testing new chemotherapeutic agents to prevent the vertical transmission of $T$. gondii during acute phase. During chronic infection Balb/c mouse is a good model to study the toxoplasmosis pathology, but not congenital transmission using $\mathrm{P}$ strain.

\section{ACKNOWLEDGMENTS}

To Ricardo T Gazzinelli for critical reading of the manuscript, Anthony B Rylands for english review and Rosálida EN Lopes for technical assistance.

\section{REFERENCES}

Alexander J, Jebbari H, Bluethmann H, Brombacher F, Roberts CW 1998. The role of IL4 in adult acquired and congenital toxoplasmosis. Inter J Parasitol 28: 113-120.

Camargo ME 1964. Estudo comparativo das reações de Sabin-Feldman e de immunofluorêscencia indireta, para a toxoplasmose, em 1000 soros humanos. Comportamento anômalo de alguns soros. Rev Inst Adolfo Lutz 24: 1-26.

Chang H, Comte R, Piguet PF, Pechère JC 1991. Activity of minocycline against Toxoplasma gondii infection mice. J Ant Chemoth 27: 639-645.

Desmonts G, Couvreur J 1974. Congenital toxoplasmosis. A prospective study of 378 pregnancies. N Engl J Med 290: 1110-1116.

Dubey JP, Beattie CP 1988. Toxoplasmosis of Animals and Man, CRC Press, Boca Raton, Fl, 220 pp.

Jamra LM.F, Vieira MPL 1991. Isolamento do Toxoplasma gondii de exsudato peritoneal e órgãos de 
camundongos com infecção experimental. Rev Inst Med Trop São Paulo 33: 435-441.

Remington JS, Melton ML, Jacobs L 1960. Chronic Toxoplasma infection in the uterus. J Lab Clin Med 56: 879-883.

Roberts CW, Alexander J 1992. Studies on a murine model of congenital toxoplasmosis: vertical disease transmission only occurs in BALB/c mice infected for the first time during pregnancy. Parasitology 104: 19-23.

Roberts CW, Brewer JM, Alexander J 1994. Congenital toxoplasmosis in BALB/c mouse: prevention of vertical disease transmission and fetal death by vaccination. Vaccine 12: 1389-1394.

Stahl W, Turek G 1988. Chronic murine toxoplasmosis: clinicopathologic characterization of progressive wasting syndrome. Ann Trop Med and Parasitol 82:
35-48.

Suzuki Y, Orellana MA, Wong SY, Conley FK, Remington JS 1993. Susceptibility to chronic infection with Toxoplasma gondii does not correlate with susceptibility to acute infection in mice. Infect Immun 61: 2284-2288.

Towbin H, Staehelin T, Gordon J 1979. Eletrophoretic transfer of proteins from polyacrylamide gels to nitrocellulose sheets: procedure and some applications. Proc Natl Acad Sci USA 76: 4350-4354.

Voller A, Bidwell DE, Bartlett A, Fleck, DG, Perkins M, Oldehin BA 1976. Microplate enzyme-immunoassay for Toxoplasma antibody. J Clin Pathol 29: 150-153.

Wong SY, Remington JS 1993. Biology of Toxoplasma gondii. Aids 7: 299-316. 